\title{
Malaysian students' motivation towards Physics learning
}

\author{
Salmiza Saleh* \\ School of Educational Studies, Universiti Sains Malaysia, Malaysia. \\ salmiza@usm.my
}

\begin{abstract}
:
The purpose of this survey study was to examine the level of Malaysian students' motivation with regards to the learning of Physics at the secondary school level, and its influencing factors. The study was carried out on 337 Form Four students who took Physics as a subject, from six schools in a northern state of Malaysia - three from urban areas, and three from rural. Data from the study were collected via the "Questionnaire of Students' Motivation towards Physics Learning". Respondents were required to mark the appropriate statements describing the level or the state of their motivation towards learning Physics in schools. Gathered data were then analysed quantitatively, using inferential statistical techniques. Results obtained showed that, in general, students have a moderately high motivation towards learning Physics. Although the t-test results showed that there was a significant difference between urban and rural students' motivation towards learning Physics, no significant differences were found between male and female students, with regards to their motivation. Among the factors found to exert strong influence in determining a student's motivation towards learning Physics are aspects such as relationships, stress and effort. According to the results, it was observed that, although students have encouraging motivation towards learning Physics, further analysis show that most of them think that learning the subject in schools is not that appealing.
\end{abstract}

Keywords: Physics learning; motivation; factors influencing motivation; gender; schools.

\section{Introduction}

To realize the 2020 Vision and the National Science and Technology Policy, the Malaysian Ministry of Education (MOE) has launched a mission to ensure that the student ratio in Malaysia will be 60:40 - to represent $60 \%$ science stream and $40 \%$ arts stream students in the upper secondary school, since the year 1994 (Mok, 2008). Generally, this policy aims to encourage more science students to participate in the field of health work, engineering, science education, ICT and others science related courses. The MOE was optimistic that the ratio of 60:40 between science and arts stream students can be achieved by the year 2010 through students' early exposure towards integrated science and technology curriculum. However, it is found that up to now, in most of the schools in Malaysia, the number of students pursuing science subjects is still far behind the targeted figure. Most of the schools can only provide less than $40 \%$ science students compared to arts students. At the tertiary level, a study also showed that the percentage of graduates produced by universities is only 32.4 of the targeted $60 \%$ (Utusan Malaysia, 2009).

One of the main reasons identified as the contributor to the lack of student enrollment in the science stream is that learning science subjects, especially Physics, is very difficult (Utusan Malaysia, 2009). Physics is basically a study to find the answers to the questions of 'why' and 'how' natural phenomena in daily life occur. Most students consider Physics a difficult subject, mainly due to the learning processes involved in understanding Physics, which require the learners to deal with different types of representations, such as formulas, calculations, graphics representations, and also a conceptual understanding at an abstract level (Sidin, 2004; Angell et al., 2004). Furthermore, research findings have also indicated that students' motivation to learn Physics is still very well below the acceptable level (Sidin, 2004; Utusan Malaysia, 2009). Hence, Physics has become a subject of least choice at schools, and most students have been reported to veer away from Physics related courses (except for engineering courses) at the higher level of education (Abd. Karim et al., 2006; Alexander et al., 2010). 


\section{Literature Review}

Motivation is a strong desire or passion in a person that encourages the person to try and do something in order to succeed. It is a construct that is built out of individual learning activities and experiences, and it varies from one situation or context to another (Bandura, 1997). Motivation effects student learning (Ormrod, 2000) and plays an important role in directing behavior towards a certain goal, increasing the effort and energy towards a goal, increasing the initiative and perseverance of an activity, and improves individual performance. Motivation is the key factor in keeping students in their learning process, and have been found to be the most significant factor that influences academic success (Pintrich et al., 1994).

A motivated student will take care of his education, has a positive thinking and is always eager to learn (Ross, 1999). Teaching would be meaningless if the student is not motivated, even when the capacity and capability of teachers are high (Wallberg, 1988). Self-motivation is essential to generate the potential for excellence and is inter-related with the spirit and desire to succeed (Petri, 1986), as well as having a strong impact on one's success and achievement (Singh et al., 2002). Students who have high or strong motivation have been found to possess a more positive attitude towards Physics (Ali, Ismail \& Sedef, 2010), are willing to learn the subject more effectively (Pintrich \& Maehr, 2004), and are able to contribute better in classes and in the school's overall development (Eccles et al., 1998). Highly motivated students are also generally linked to the increase in the levels of student success rates and reduced dropout rates (Dev, 1997; Blank, 1997). Therefore, understanding motivation is necessary in designing an instructional process that can attract students towards a taught subject (Fisher \& Horstendahl, 1997).

It is well known that student motivation is influenced by both internal and external factors that can start, sustain, intensify or discourage behaviors (Reeve, 1996). Internal factors include the individual characteristics or dispositions that a student brings towards his learning activity such as interest, responsibility for learning, effort, values and perceived ability (Ainley, 2004). On the other hand, external factors include external rewards that come from the outside of the individual, such as money, praises and grades. Study results have indicated that individuals who are intrinsically motivated, compared to those who are extrinsically motivated, retain information and concepts longer (Dev, 1997), have more interest, excitement, fun, and confidence, which leads to enhanced performance, creativity, persistence, vigor, general well-being, and self-esteem, as well as more likely to be lifelong learners (Kohn, 1993; Ryan \& Deci, 2000). Therefore, finding the ways to enhance intrinsic motivation for students is of utmost importance.

In the context of Physics learning worldwide, it is found that there are far fewer students taking Physics than any other science subjects at the higher level of education (Dawson, 2000; Osborne et al., 2003; Lyons, 2006; Abd. Karim et al., 2006; Owen et al., 2008). There is a consensus among students and people in general, including teachers, that Physics is a very difficult subject (Lavonen et al., 2007; Lyons 2006; Angell et al. 2004; Sidin, 2004; Osborne et al., 2003; Stokking, 2000), which influences the motivation to learn Physics. As for the students themselves, much of the Physics curriculum is often considered boring, uninteresting and irrelevant (Lavonen et al., 2007; Lyons, 2006; Angell et al., 2004). Furthermore, students' interest towards Physics have been found to be on the decline across the phases of study (Murphy \& Whitelegg, 2006; Reid, 2003). The most pronounced decline in the interest towards Physics, especially for female students, is associated with the increase of negative feelings towards the Physics subject in school (Murphy \& Whitelegg, 2006).

Male students, in general, are found to be more interested in the aspects of physical sciences, while female students' interests in science are focused more on the biological and environmental aspects (Murphy \& Whitelegg, 2006). Therefore, male students tend to be more motivated in learning Physics than female students (Stadler et al., 2000; Alexander et al., 2010). A study on students aged between 11-15 years old showed that (i) $63 \%$ of male students enjoy learning science compared to $42 \%$ of female students, (ii) $37 \%$ of male students like science subjects compared to only $6 \%$ of female students, and (iii) only $22 \%$ of female students like Physics compared to $37 \%$ of them who like 
chemistry and 63\% who like biology (Warrington \& Younger, 2000). At the initial stages of secondary school, the difference between boys' and girls' views of science, between the ages of 13 to 14, increased, with girls' interest in science declining along with their view of their competence in science, towards the end of the age range (Reid \& Skryabina, 2002). It has also been found that traditionally, girls' interest in Physics decreases as they grew older (Hoffmann, 2002; Dawson, 2000). Compared to male students, female students are found to have more negative views of Physics (Osborne \& Collins, 2000). Although male students are found to have a higher self-concept towards Physics, female students, on the other hand, despite their decreased interest and negative views, tend to perform significantly better than boys in Physics, and rated Physics as their favourite subject (Joshi \& Srivastava, 2009).

Studies conducted by DuBois et al. (2002) found that environmental factors also play an important role in determining an individual's motivation level. Students from urban areas are generally found to have higher motivation than those coming from rural areas (Abdul Rahman, 1980). Rural students have been found to exhibit lower performance, due to the lack of exposure to a stimulating environment (Markstrom et al., 2000), such as the narrow scope of curriculum in their schools, instructional practices that constrain individual opportunities for acceleration and remediation, and lack of access to the supports and resources of programs, organizations, and educational institutions prevalent in urban and suburban areas (Redding \& Walber, 2012). A longitudinal study done by Felder et al. (1994) on learning performance and retention of urban and rural students showed that there are significant differences in the results obtained between the groups. Urban students have been found to perform better on almost every measurable scale investigated, and continue to earn higher grades in their courses, throughout the entire duration of their studies (Felder et al., 1994).

\section{Problem Statement}

In Malaysia, it has been found that the level of educational achievement in the subject of Physics is deemed somewhat less satisfactory. Although the percentage of students who passed the Physics paper in the Malaysian Certificate of Education (MCE) examinations, equivalent to the British O-Level studies, has increased over years, student achievement in terms of overall subject performance in Physics is yet to be proud of. The 2009 MCE examination data reveals that only about $20.0 \%$ of the students achieved excellent results in the Physics paper, and this phenomenon has been quite consistent for a couple of years running. Students, on the whole, have not been quite able to excel in the subject of Physics. To top it all off, an array of researches conducted within the same period has also shown that the majority of students are actually not interested in studying Physics. Most students find Physics a difficult subject, and unappealing. This concern is not only prevalent at the school levels, but also at higher learning institutions such as colleges and universities. An alarmingly high number of students have also been found to refrain themselves from taking any Physics-related courses at higher levels of education.

The lacklustre performance of students' examination results, in addition to their vocally expressed lack of interest in the subject of Physics, has raised the following questions: Do these problems occur due to the lack of motivation to learn Physics among students? If so, what are the factors that cause them to think so? This study was conducted to find out the answers to these questions.

\section{Purpose of Study}

This study was conducted to explore students' motivation to learn Physics, as well as factors influencing their motivation to learn the subject. In particular, the research questions are as follows:

- What are the students' perceptions of teaching and learning Physics in school?

- What is the level of motivation to learn Physics among students?

- What are the factors that influence the level of motivation to learn Physics among students?

- Is there any difference in motivation to learn Physics between male and female students?

- Is there any difference between urban students' motivation to learn Physics compared to rural students? 


\section{Significance of Study}

As research on student learning motivation, especially on the subject of Physics, is not very well documented, the results of this study would be quite useful, especially as reference material for researchers in related fields, to conduct further research for the purpose of improving existing methods of teaching Physics. The data obtained can serve as important empirical evidence about the status of Physics learning motivation among students at the present time. The study is also expected to provide guidance to teachers about the level of secondary school students' motivation towards the subject of Physics, and can help prompt the required changes to be made, if desired, to the teaching and learning methods to promote student interest and motivation.

\section{Research Methodology}

This study adopted a survey method to collect the required data. The study was conducted in 6 schools ( 3 urban schools, 3 rural schools), randomly selected in a northern state in Malaysia. The research sample consisted of 337 Form Four science students who took Physics at these schools. Convenience sampling techniques (respondents are ready to cooperate with the researcher) have been used to ensure the success of this study. The motivation questionnaires were distributed to the schools to be given to the respondents. Students were required to answer the questionnaires honestly within 60 minutes during school hours, arranged by the school administrators. The questionnaires were then collected after the students have completed their answers.

\section{Questionnaire}

The Questionnaire of Students' Motivation towards Physics Learning (QSMPL) was developed by adapting items from the instrument known as the Intrinsic Motivation Inventory (IMI). Items have been selected based on their relevance to the issues explored by the researcher. IMI has been used in several studies on intrinsic motivation and the nature of the self (Plant \& Ryan, 1985; Ryan et al., 1994). The items in IMI have been shown to be coherent in terms of analytical and stable factor in a variety of tasks, situations and settings (Ryan et al., 1991). The study conducted by McAuley et al., (1987) also found that this instrument has high validity. Previous studies have shown that the effect of the order of items can be ignored and that the entry or withdrawals of any subscales do not have an impact on other aspects (Ryan et al., 1991).

In general, the QSMPL consists of thirty six items, within seven main motivational subscales: (a) interests / preferences - five items; (b) understanding - six items; (c) selection - three items; (d) effort / importance - four items; (e) pressure / tension - eight items; (f) value / use - five items; and (g) relationship - four items. Each item has a four-level Likert Scale degree of agreement, namely: 1Strongly Disagree; 2 - Disagree; 3 - Agree; and 4 - Strongly Agree. Students are asked to rate their degree of agreement to all 36 items in the questionnaire. The final score is the sum of their ratings for all of the items.

\section{Statistical Analysis}

The data collected from the questionnaires are then processed using Statistical Package for Social Science (SPSS) version 15.0. Descriptive statistics is used to describe demographic data and involves the mean, median, mode, and standard deviation, whereas inferential statistics, involving independent samples t-test and Anova test, is used to determine the differences between the groups involved in the research.

\section{Results and Discussion}

\section{Students' Perception of Physics}

The results showed that most students (> 75.0\%) felt that learning Physics in school is boring and they agree that Physics instructional methods were unable to attract their attention. $82.63 \%$ of the students 
agreed that learning Physics was unable to help them to achieve their ambitions. $53.57 \%$ of the students were also dissatisfied with their achievement in Physics education. $66.88 \%$ of the students admit to fully participate in the learning activities held. $79.87 \%$ of the students felt forced to do the given Physics tasks in the classroom.

The results obtained are found to be consistent with previous research findings (Lavonen et al., 2007; Lyons, 2006; Angell et al., 2004), which stated that in general, Physics is often considered by students as a boring, uninteresting and irrelevant subject. If this is used as a general guide, the data obtained show that Physics learning in Malaysian schools is not enjoyable. Since the study has shown that the excitement of studying a particular field plays an important role in determining students' preferences (Reid \& Skryabina, 2002), a serious revision to the teachers' instructional approaches practiced in the classroom should be considered. Teachers play a very important role in ensuring students' interest towards Physics and the related self-concept. Their attitude can empower or marginalize students in the subject and their practices are the key to the change in students' performance in Physics.

\section{Students' Level of Motivation to Learn Physics}

In general, it was found that students' level of motivation to learn Physics is at a moderately high level, with an average score of 3:05 on the Likert Scale.

\section{Factors influencing the level of motivation to learn Physics among students}

Table 1 shows that for the subscale of understanding, the average score for female students is 2.71 and for male students, it is 2.77. (The maximum Likert Scale score is 4.00). These findings show that male students have a slightly better understanding of Physics concepts compared to female students. The results support Gurian and Stevens' (2004) findings, which concluded that male students are better in understanding abstracts Physics concepts than female students.

Table 1. Likert Scale average score for factors influencing the level of motivation to learn Physics among female and male students

\begin{tabular}{lcccc}
\hline & \multicolumn{2}{c}{ Female } & \multicolumn{2}{c}{ Male } \\
\cline { 2 - 5 } & Average & Percent & Average & Percent \\
\hline Understanding & 2.71 & $67.85 \%$ & 2.77 & $69.47 \%$ \\
Interests / Preferences & 2.84 & $71.01 \%$ & 2.74 & $68.55 \%$ \\
Effort / Importance & 3.05 & $76.26 \%$ & 3.01 & $75.46 \%$ \\
Selection & 2.75 & $68.86 \%$ & 2.66 & $66.67 \%$ \\
Value / Use & 2.99 & $74.85 \%$ & 2.98 & $74.55 \%$ \\
Relationship & 3.30 & $82.51 \%$ & 3.04 & $76.02 \%$ \\
Pressure / Tension & 3.10 & $77.65 \%$ & 3.01 & $75.29 \%$ \\
\hline
\end{tabular}

For the subscale of interest / preferences, the average score for female students is 2.84 , while male students score 2.74. These findings show that interest / preferences play a more important role in motivating female students to learn Physics than for male students. The results are slightly different from the previous findings, which generally found that male students are more interested to learn Physics than female students.

For the subscale of efforts / importance, the average score for female students is 3.05, while for male students, the score is 3.01. These findings show that both female and male students have quite a similar perception towards effort / importance of Physics as a subject. In addition, this subscale also recorded the highest average scores for both the genders. Students are generally affected by intrinsic motivation to learn Physics. Most of them agree with the statement that they have to work hard to get a good result in Physics, due to the importance of this subject in order to pursue higher level education in science-related fields. 
For the subscale of selection, the average score for female students is 2.75 , while male students score 2.66. This subscale had the lowest average score for both the genders. The results show that students generally do not have a variety of options in their classroom for Physics learning activities.

For the subscale of value / use, the average score for female students is 2.99 , while for male students, it is 2.98. There is not much difference between female and male students' scores in this subscale. Students as a whole agree that the value / use help increase their motivation to learn Physics. They agree that learning activities carried out in the classroom are beneficial to them.

For the subscale of relationship, the average score for female students is 3.30, while for male students, the score is 3.04. Female students score higher than male students in this subscale. This is appropriate because female students are basically more concerned about their interpersonal relationships than boys, who tend to be more independent in their lives.

For the subscale of pressure / tension, the average score for female students is 3.10, while male students score 3.01. The findings show that most students feel that learning Physics in school is boring and are not attracted to the learning methods practiced in schools. The results are consistent with previous studies, indicating that Physics instructional methods in schools are boring and not interesting.

Table 2. Likert Scale average score for factors influencing the level of motivation to learn Physics among students

\begin{tabular}{lc}
\hline Motivation subscale & Likert Scale average score \\
\hline Relationship & 3.21 \\
Pressure / tension & 3.07 \\
Effort / significance & 3.04 \\
Value / use & 2.98 \\
Interest & 2.81 \\
Understanding & 2.74 \\
Option & 2.72 \\
\hline
\end{tabular}

Overall, based on Table 2 above, it is found that the factor that affects most of the students' motivation to learn Physics is relationship, followed by stress, effort, value, interest, understanding and, last but not least, selection.

\section{Gender Differences in Motivation to Learn Physics}

Results from Table 3 show that the score of male students is 2.90 whereas the score for female students is 2.98, on the Likert Scale. The t-test results (Table 4) show that there is no significant difference between male and female students' motivation to learn Physics. (Levene test: $\mathrm{F}=3.08, P=0.08$; $\mathrm{t}=$ $1.12, P=0.26)$.

Table 3. Comparison of minimum score, maximum score, average score and standard deviation on the Likert Scale for Physics learning motivation between male and female students

\begin{tabular}{c|ccccc}
\hline \multicolumn{1}{c|}{ Group } & $\mathrm{N}$ & $\begin{array}{c}\text { Minimum } \\
\text { Score }\end{array}$ & $\begin{array}{c}\text { Maximum } \\
\text { Score }\end{array}$ & $\begin{array}{c}\text { Average } \\
\text { Score }\end{array}$ & $\begin{array}{c}\text { Standard } \\
\text { Error }\end{array}$ \\
\hline Male Students & 145 & 1.60 & 3.83 & 2.90 & .459 \\
\hline Female Students & 192 & 1.74 & 3.83 & 2.98 & .388 \\
\hline
\end{tabular}


Table 4. T-test analysis for Physics learning motivation between male and female students

\begin{tabular}{ccc|ccccc}
\hline \multicolumn{3}{c|}{ Levene Test } & \multicolumn{6}{c}{ T-test } \\
\hline & $F$ & Sig. & $\mathrm{t}$ & Df & Sig. & $\begin{array}{c}\text { Mean } \\
\text { Difference }\end{array}$ & $\begin{array}{c}\text { Standard } \\
\text { Error } \\
\text { Difference }\end{array}$ \\
$\begin{array}{c}\text { Equal } \\
\text { variances } \\
\text { assumed }\end{array}$ & 3.08 & .08 & 1.12 & 152 & .26 & .08 & .07 \\
\hline
\end{tabular}

*Significant level: 0.05

This result is not consistent with previous studies. The findings are contrary to what has been reported by Murphy and Whitelegg (2006), which stated that at the age of 15, compared to male students, female students are less interested in Physics and tend to avoid this subject. A different phenomenon occurs in Malaysia, however. In general, both male and female students are found to be motivated to learn Physics the age of 15 plus. This factor may be due to the implemented open certification in the Malaysian Certificate of Education (MCE), practiced since the year 2000 in the Malaysian educational system, which provides options for students to choose their interested science subjects to be pursued. This means that students who choose this subject are students who really are interested in Physics. The results also contradict the findings of Murphy and Whitelegg (2006), which indicated that compared to male students, female students' Physics self-concept decline over time and the findings of Joshi and Srivastava, (2009) who found that compared to male students, female students are found to have a higher motivation to learn Physics.

\section{Differences between Urban and Rural Students' Motivation to Learn Physics}

Results from Table 5 show that the score of urban students is 3.11 whereas the score for rural students is 2.85 on the Likert Scale. The t-test results (Table 6) show that there is a significant difference between urban students' motivation to learn Physics compared to rural students. (Levene test: $\mathrm{F}=$ $14.42, P=0.00 ; \mathrm{t}=4.40, P=0.00)$.

Table 5. Comparison of minimum score, maximum score, average score and standard deviation on the Likert Scale for Physics learning motivation between urban and rural students

\begin{tabular}{l|ccccc}
\hline Group & $\mathrm{N}$ & $\begin{array}{c}\text { Minimum } \\
\text { Score }\end{array}$ & $\begin{array}{c}\text { Maximum } \\
\text { Score }\end{array}$ & $\begin{array}{c}\text { Average } \\
\text { Score }\end{array}$ & $\begin{array}{c}\text { Standard } \\
\text { Error }\end{array}$ \\
\hline $\begin{array}{l}\text { Urban School } \\
\begin{array}{l}\text { Students } \\
\text { Rural School } \\
\text { Students }\end{array}\end{array}$ & 147 & 2.51 & 3.83 & 3.11 & 0.27 \\
\hline
\end{tabular}

Table 6. T-Test analysis for Physics learning motivation between urban and rural students

\begin{tabular}{|c|c|c|c|c|c|c|c|}
\hline \multicolumn{3}{|c|}{ Levene Test } & \multicolumn{4}{|c|}{ T-test } & \multirow[b]{2}{*}{$\begin{array}{l}\text { Standard } \\
\text { Error } \\
\text { Difference }\end{array}$} \\
\hline & $\mathrm{F}$ & Sig. & $t$ & Df & Sig. & $\begin{array}{c}\text { Mean } \\
\text { Difference }\end{array}$ & \\
\hline $\begin{array}{l}\text { Equal } \\
\text { variances not } \\
\text { assumed }\end{array}$ & 14.42 & .00 & 4.40 & 151.609 & .00 & .26 & .06 \\
\hline
\end{tabular}


These findings are consistent with previous results which indicated that in general, rural students are left quite behind their urban counterparts in their academic achievements. These findings are also in line with what has been reported by Abdul Rahman (1980) and Felder et al. (1994), which stated that urban students have a higher level of achievement in motivation, as compared to rural students.

As rural students get less information about most aspects of educational advantages, particularly in relation to Physics, as well as lower educational aspirations, in addition to the expectations of working with a lower income, compared to urban students (Young et al., 1997), these findings would mean that more attention should be given to this group of students.

\section{Conclusion}

Based on the results obtained in this study, it can be concluded that in general, although these students have been found to have a moderately high motivation to learn Physics, most of them still have a rather negative perception of learning Physics in school, compared to other subjects. In terms of the dimensions of motivation, it was found that the relationships subscale has the greatest influence towards students' motivation to learn Physics, followed by pressure / stress, effort / significance, value / use, interest, understanding, and choice. The results show that there is no significant difference between male and female students' motivation to learn Physics in schools. However, there is a significant difference between rural students' and urban students' motivation to learn Physics, whereby urban students do have a higher motivation compared to rural students.

\section{Implications}

This study shows that Malaysian high school students in the northern region generally have an encouraging motivation to study Physics, considering that the subject is chosen by most of them through an open education system practiced in this country. Even so, further analysis shows that most students consider their Physics learning activities in school less interesting and quite boring. These findings explain the phenomenon of why a majority of Malaysian students tend to avoid Physics related courses at the tertiary education level, even though they have an encouraging motivation to learn Physics at an earlier stage. This is probably due to the high school Physics education system that is less effective in retaining students' motivation and as a result, the motivation level drops across the phases of study (Murphy \& Whitelegg, 2006). Therefore, the Physics education process in schools is recommended to focus on developing students' intrinsic motivation so that the interest towards this subject is not derailed, due to the constraints of teaching and learning processes that may not meet their needs.

\section{Acknowledgements}

This study was supported by Universiti Sains Malaysia 'Research University' Grant.

\section{References}

Abd. Karim, M., Hussain, B.H., Md. Yusoh, O., Abd. Razak, N., Musa, M., Rahmat, F., and Azmi, N. (2006). “Kajian profil kemasukan dan prestasi pelajar Fakulti Sains dan Teknologi,UPSI. Penerbit Universiti Perguruan Sultan Idris" http:/ / www.kajianprofilkemasukandanprestasipelajarUPSI, (accessed December 2006)

Abd. Rahman, W.R. (1980). Peranan motivasi pencapaian dalam pembentukan usahawan: Satu kajian di kalangan murid-murid sekolah di Malaysia dan United Kingdom. Kertas Seminar dalam Seminar Psikologi dan Masyarakat.

Alexander SY, Kuppam L, Shaik Kadir M \& See KF. (2010). Boys' and Girls' Self-beliefs, Engagement, and Aspirations in Physics. The International Journal of Learning. 17(10), 397-418

Ali, E., Ismail, Y., and Sedef, A. (2010). Investigating of Relationships between Attitudes towards Physics Laboratories, Motivation and Amotivation for the Class Engagement. Eurasian J. Physics and. Chemistry Education, Jan (Special Issue), 5964.

Ainley, M. (2004). Connecting with learning: Motivation, affect and cognition in interest process. Educational Psychology Review, 18(4), 391-405

Angell, C., Guttersrud, Ø., Henriksen, E. K., and Isnes, A. (2004). Physics: Frightful, but fun, Pupils' and teachers' views of Physics and Physics teaching [Electronic version]. Science Education, 88, 683-706.

Bandura, A. (1997). Self-Efficacy: The exercise of control. New York, NY: W.H. Freeman.

Blank, W. (1997). Authentic instruction. In W.E. Blank \& S. Harwell (Eds.), Promising practices for connecting high school to the real world (pp. 15-21). Tampa, FL: University of South Florida. (ERIC Document Reproduction Service No. ED 407 586) 
Dawson, C. (2000). Upper primary boys' and girls' interests in science: Have they changed since 1980? International Journal of Science Education, 22(6), 557-70.

Deci, E. L, Eghrari, H., Patrick, B. C., and Leone, D. (1994). Facilitating internalization the self-determination theory perspective. Journal of Personality, 62,119- 142.

Dev, P. C. (1997). Intrinsic Motivation and Academic Achievement: What Does Their Relationship Imply for the Classroom Teacher? Remedial \& Special Education, 18(1), 12-19.

DuBois, D., Burk-Braxton, C., Swenson, L., Tevendale, S., and Hardesty, J. (2002). Race and gender influences on adjustment in early adolescence: Investigation of an integrative model, Child Development, 73, 1573-1593.

Eccles, J., Wigfield, A., and Schiefele, U. (1998). Motivation to succeed. In W. Damon (Series Ed.) \& N. Eisenberg (Vol. Ed.), Handbook of child psychology: Vol. 3. Social, emotional, and personality development (5th ed., pp. 1017-1095). New York: Wiley.

Felder, R. M, Mohr, P. H., Dietz, E. J., and \& Baker-Ward, L. (1994). A Longitudinal Study of Engineering Student Performance and Retention. II. Differences Between Students from Rural and Urban Backgrounds, Journal of Engineering Education, 83(3), 209-217

Fischer, H. E., and Horstendahl, M. (1997). Motivation and Learning Physics. Research and Science Education, 27(3), 411-424.

Freeman, T. M., \& Anderman, L. H. (2005, January 12). Changes in mastery goals in urban and rural middle school students. Journal of Research in Rural Education, 20(1). Retrieved [date] from: http://www.umaine.edu/jrre/20-1.pdf

Gurian, M. and Stevens, K. (2004). With Boys and Girls in Mind. Educational Leadership. 62 (3), 21-26.

Hoffmann, L. (2002). Promoting girls' interest and achievement in physics classes for beginners. Learning and instruction, 12(4), 447-465.

Joshi S, Srivastava R. Self-esteem and Academic Achievement of Adolescents. Journal of the Indian Academy of Applied Psychology. 2009;35:(Special Issue),33-39.

Kannapel, P. J., and DeYoung, A. J. (1999). The rural school problem in 1999: A review and critique of the literature. Journal of Research in Rural Education, 15, 67-79.

Kohn, A. (1993). Punished by rewards: The trouble with gold stars, incentive plans, A's, praise, and other bribes. Boston, MA: Houghton Mifflin.

Lavonen, J., Angell, C., Bymen, R., Henriksen, E., and Koponen, I. (2007). Social interaction in upper secondary physics classrooms in Finland and Norway: A survey of students' expectations. Scandinavian Journal of Educational Research, 51(1), 81-101.

Lee, M.N., Yoong, S., Loo, S. P, Zon, K., Ghazali, M., and Lim, C. S. (1996). Students orientation towards Science and Mathematics: Why are enrolments falling? Monograph 1, Pusat Pengajian Ilmu Pendidikan, USM. Penerbit Universiti Sains Malaysia.

Lyons, T. (2006). The puzzle of falling enrolments in physics and chemistry courses: putting some pieces together. Research in Science Education, 36(3), 285-311.

Markstrom, C. A., Marshall, S.K., \& Tryon, R. J. (2000). Resiliency, social support and coping in rural low income Appalachian adolescents from two racial groups. Journal of adolescence, 18, 145-172.

McAuley, E., Duncan, T., and Tammen, V. V. (1997). Psychometric properties of the Intrinsic Motivation Inventory in a competitive sport setting: A confirmatory factor analysis. Research Quarterly for Exercise and Sport, 60, 48-58.

Mok, S. S. (2008). Ilmu Pendidikan Untuk KPLI (Sek. Rendah:Komponen 1 \& 2). Psikologi Pendidikan \& Pedagogi. Kumpulan Budiman Sdn. Bhd., Subang Jaya.

Murphy, P., and Whitelegg, E. (2006)." Girls in the Physics Classroom. A Review of the research on the participation of girls in Physics. Institute of Physics Report." http://www.iop.org/education/teacher/support/girls_Physics/review/file41599.pdf, (accessed March 2010)

Ormrod, J. E. (2000). Educational Psychology (3rd ed.) Upper Saddle river, NJ: Merrill/Prentice Hall.

Osborne, J., and S. Collins (2000). Pupils' and Parents' Views of the School Science Curriculum. London, Wellcome Trust.

Osborne, J., Simon, S., and Collins, S. (2003). Attitudes towards science: a review of the literature and its implications. International Journal of Science Education, 25(9), 1049-1079.

Owen, S., Dickson, D., Stanisstreet, M., and Boyes, E. (2008). Teaching physics: Students' attitudes towards different learning activities. Research in Science \& Technological Education, 26(2), 113-128.

Petri H. L. (1986). Motivation Theory and Research, 2nd edition. USA: Wadsworth Publication.

Plant, R.W. \& Ryan, R.M. (1985). Intrinsic motivation and the effect of self-conciousness, self-awareness and egoinvolvement: An investigation of internally-controlling styles. Journal of Personality, 53, $435-449$.

Pintrich, P. R., and Maehr, M. L. (Eds.). (2004). Advances in motivation and achievement: Motivating students, improving schools (Vol. 13). Oxford, England: JAI, An Imprint of Elsevier Science.

Redding, S., and Walberg, H.J (2012). "Promoting Learning in Rural Schools. Center of innovation and Improvement. Academic Development Institute." http://www.centerii.org/survey/downloads/Promoting Learning_in Rural Schools.pdf. (accessed July 2012)

Reeve, J. (1996). Motivating others. Nurturing inner motivational resources. Needham Heights: MA: Allyn \& Bacon.

Reid, N., and E. A. Skryabina (2002). Attitudes towards Physics. Research in Science and Technological Education. 20(1) 67-80.

Ross C. M. (1999). The Relationship among Academic Achievement Motivation, Motivation Orientation, and Ability-Achievement Differences in Reading. Phd. University of Alabama, USA.

Ryan, R.M. 1982. Control and information in the intrapersonal sphere: An extension of cognitive evaluation of theory. Journal of Personality and Social Psychology, 43, 450 - 461.

Ryan, R.M, and Deci, E L. (2000). Intrinsic and extrinsic motivations: Classic definitions and new directions. Contemporary Educational Psychology, 54-67.

Ryan, R. M., Koestner, R., and Deci, E.L. (1991). Varied forms of persistence: When free-choice behaviour is not intrinsically motivated. Motivation and Emotion, 15, 185 - 205

Sidin, R. (2003). Pembudayaan Sains dan Teknologi: Satu Cadangan Piawai [Socialization of science and technology: a standard proposal]. Jurnal Pendidikan (UKM), 47-63.

Singh, K., Granville, M., and Dika, S. (2002). Mathematics and science achievement: Effects of motivation, interest and academic engagements. The Journal of Educational Research, 95(6), 323-332.

Stadler, H., Duit, R., and Benke G. (2000). Do boys and girls understand physics differently? Physics Education. 35(6):417-422. 
Stokking, K. (2000). Predicting the choice of physics in secondary education. International Journal of Science Education, 22(12), 1261-83.

Utusan Malaysia. (2009). "Dasar 40:60 pelajar sastera sains belum tercapai." http:/ /2pendidikmy.blogspot.com/2009/03/dasar-4060-pelajar-sastera-sains-belum, (accessed March 2009)

Walberg, H. J. (1988). Creativity as learning. In R. J. Sternberg (Ed.), The nature of creativity (pp. 340-361). New York: Cambridge University Press.

Warrington, M. and M. Younger (2000). The other side of the gender gap. Gender and Education, 12(4), 493-508.

Woolfolk, A. (2001). Educational Psychology, Eighth Edition. Boston, Allyn and Bacon.

Young, D.J., Frazer, B. J., \& Woolnough, D. E. (1997). Factors affecting student career in science: An Australia study of Rural and Urban Scools. Research in Science Education, 27(2), 195-214. 